\title{
DIE PASTORALE BEARBEIDING VAN DIE GESKEIES
}

\author{
PROF. DR. F. J. VAN ZYL
}

1 (i) Dit gaan in die pastorale sorg om die uitoefening van 'n bepaalde aspek van die herdersamp. Die Formulier vir die bevestiging van Dienaars van die Woord verklaar dat die dienswerk van die predikant maklik afgelei kan word uit die woord ",herdersamp". Dit gaan daarin om twee sake:

* verskaffing van weiding aan die kudde

* * leiding en regering van dieselfde kudde.

Die weiding waarmee hierdie kudde gevoed word en die staf waarmee hy gelei en geregeer word is die een Woord van God. In die bearbeiding van die geskeie persoon gaan dit om die hantering van die staf van die Woord, of anders gesê, dit val onder die opsig taak van die predikant wat wesenlik woorddiens is aan die enkeling in die vorm van die pastorale gesprek.

1 (ii) Die reeds genoemde formulier onderstreep die besondere betekenis van die herdersamp as hy daarop wys dat dit 'n besondere genade is wat aan 'n mens bewys word wanneer God deur sy menslike diens vir Hom 'n gemeente wil roep en vergader tot die ewige lewe of die saligheid. Die herderswerk is in albei sy aspekte van voeding met en regering deur die Woord van God derhalwe 'n uiters belangrike aangeleentheid. As jy daarop let dat dit in hierdie werk gaan om die ewige bestemming en geluk van mense, besef jy dat daardeur ' $n$ byna te groot verantwoordelikheid op die dienaar van die Woord gelê word, wat self ook maar 'n falende en fouterende sondige mens is. Maar juis daarom moet hy des te meer waak teen nalatigheid en onverskilligheid.

\section{Doel van die pastorale sorg}

2(i) Die oogmerk van die pastorale sorg as opsigtaak van die herder en leraar, is om cll:e lid van die kerk in leer en lewe onder die gesag en tug van die Helige Skrif te laat volhard. Waar daar tekens van verontagsaming on ongehoorsaamheid is aan die voorskrif van Cods Woord, moct vermaan en berispe, bemoedig en versterk word. As die opsig nie die beoogde resultaat lewer nie, moet die bearbeiding verskerp en toegespits word in die tug met in agneming van al die voorgeskrewe stadia daarvan.

2(ii) Let 'n mens op die plek van die huwelik in die Heidelbergse Kategismus, dien daarop gelet te word dat dit ter sprake kom onder die sewende gebod as deel van die dankbaarheid. Die 
huwelik is wel 'n instelling van God wat onder sy gebod gestel is, maar dit is nie noodsaaklik vir 'n mens se saligheid nie omdat God geen heilsbelofte aan hierdie instelling verbind het nie. Omdat ' $n$ sekere deel van ' $n$ mens se lewe, en in normale omstandighede die belangrike en langste deel daarvan, $\mathrm{nl}$. die getroude lewe onder die gebod van God gestel is, beteken ongehoorsaamheid aan hierdie gebod, sonde teenoor God.

\section{Die kerk se houding teenoor die sersende gebod}

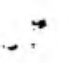

$3(i)$ Daar is ' $n$ opvallende teenstrydigheid of ongerymdheid in ons kerk se houding teenoor die sewende gebod. Aan die een kant word daar streng vermanend-tugtend opgetree teen oortreders van hierdie gebod waar dit voorhuwelikse kinderverwekking betref. Die invloed van die Heidelbergse Kategismus is hier baie duidelik. Hy verklaar die gebod immers as 'n vervloeking deur God van alle onkuisheid binne en buite die huwelik. Die streng houding van die kerk staan ook in verband met die bewaring van die heiligheid van die sakrament. Aan die ander kant is daar by die kerk oor die algemeen ' $n$ minder strenge houding aanwesig in soverre dit die oortreding van die sevende gebod betref in die $\sin$ van verbreking van die huwelik. Heel dikwels kom 'n egskeiding eers onder die aandag van die predikant by die varsoek tot die bevestiging van ' $n$ tweede huwelik, of deur die toevallige ofsporing tydens die jaarlikse sensus van twee geskeies wat reeds getroud is en miskien geruime tyd reeds binne die grense van die gemeente woon. Hierdie ongewensde toedrag van sake sal seker aan verskillende faktore toegeskryf kan word. Aan die een kant werp dit 'n effens ongunstige lig op die stand van die pastorale sorg in die kerk as mense in sulke krisisomstandighede nie die hulp en die bystand van die kerk inroep nie. Dit is miskien ook ' $n$ teken van die innerlike vervreemding van kerk en evangelie wat daar by baie lidmate gevind word. Aan die ander kant kan 'n mate van maatskaplike verleentheid wat met egskeiding gepaard gaan, ' $n$ rede wees waarom die voorspel tot die fatale stap dikwels geheim gehou word. Hierdie toedrag van sake word beslis in die hand gewerk deur die tekort aan predikante waardeur predikante verplig word om sulke groot gemeentes te bearbei dat daar nie tyd is om die nodige aandag na behore aan die individuele lidmate bestee kan word nie. Net so noulettend as wat die kerk nog altyd was t.o.v. die sewende gebod waar dit die onkuisheid betref, moet hy dit ook wees wat die verbreking van die huwelik betref. Soms word die beswaar gehoor dat die kerk ongeregverdig eensydig is as hy so streng optree t.o.v. die sewende gebod in teenstelling met die nnder gebojie betreffende sondagsheiliging, diefstal, valse getuienis en so meer. Daar is die Bybel egter ook getuienis waardeur die huweliksaspek van die sewende 
gebod tot ' $n$ mate uitgelig word tussen die ander gebooie, veral van die tweede tafel. Die huwelik is immers ' $n$ instelling van God, dis die fondament van 'n familie, 'n geslag, ' $n$ volk. Ook die kerk bestaan uit huisgesinne en elke gelowige man en vrou wat saamkom in die huwelik is 'n kerk in die klein. Gesonde huisgesinne, stewige huwelike in gehoorsaamheid aan God se gebod is van onberekenbare betekenis vir kerk en volk.

\section{Nadere bepaling van die problematiek}

4(i) In die pastorale bearbeiding van die geskeie persoon het ' $n$ mens met ' $n$ redel'k komplekse probleem te doen met verskillende aspekte van wisselende intensiteit. Die geskeie kan iemand wees met wie die piedikant die hcle opdraande of afdraande pad voor die egskeiding saamgeloop het. Hy kan dus ' $n$,meelewende" lidmaat wees. Elke predikant sal kan getuig dat sulke gevalle tot ' $n$ mate die minder moeilikes is omdat daar hy hierdie mense kennis en begrip is vir die kerk se stem. Moeiliker word dit as die geskeie uit die randgebied van die kerk kom waar eie geloofsoortuiging en kennis van die kerk nog net 'n gevaarlike dun lagie is, en nog moeiliker word dit as hierdie persoon eers voor jou staan nadat die huwelik sonder enige kerklike byhandeling reeds ontbind is. ' $n$ Ander, nog moeiliker situasie duik op as die twee geskeie reeds hertrou het (of een gesleeie) sonder dat daar enige kerklike handeling plaasgevind het voor of na die egskeiding. Al hierdie gevalle verdien die aandag van die pastor. Almal kan nie afsonderlik deur my nou behandel word nie. Aangesien ek teoreties die vryheid van keuse besit, verkies $\mathrm{ck}$ om " $\mathrm{n}$,,normale" geval as voorbeeld te neem met die hoop dat vandaar nuttige lyne getrek sal kan word na die meer gekompliseerde gevalle. Mv keuse is ' $n$ gewone lidmaat van die kerk wat geskei is en nog nie hertrou het nie.

4(ii) Voordat ek verder gaan moet die pastorale sorg van geskeie persoon ter sprake kom. Dit gaan in die woorddiens van die kerk in al sy gestaltes. ook in die pastoraat. om drie momente waarvan nie een vervsaarloos moet word r:c. Dit gaan om wat 'n mens sê en hoe jy dit sê en aan wie jy dit sê. Oor die wat sal later gehandel word. Hier gaan dit om die hoe en die wie. Teen die agtergrond van wat heel aan die begin gesê is, gaan dit om iemand wat God in die ewige lewe wil hê - om die taal van die formulier te gebruik. Hy moet vir ons derhalwe nie sommer maar , in ou" wees vir wie ons nie veel omgee nie en wie se geval vir ons eintlik net 'n lastigheid is nie. Dit moet iemand wees met wie ons persoonlik worstel ter wille van die ryk van Christus. Die woord wat ons spreek sal by uitstek ' $n$ vermanende woord wees, maar ' $n$.,parakalein" wat gedra word deur 'n pleit, 'n bede, ' $n$ bewoënheid wat sy oorsprong het by die „oiktirmoi" van God. 
4 (iii) Die geskeie kan iemand wees met 'n lang pad van deurvoelde lyding agter die rug, iemand wat miskien meer as een keer ernstig probeer het om ' $n$ nuwe begin te maak sonder sukses. Dis in elk geval iemand met 'n ontwrigte lewe wie se geloof waarskynlik ook tot die uiterste beproef is. Daar mag nog ander faktore wees wat hom 'n moeilike objek van bearbeiding maak. Behalwe die feit dat daar by hom geen twyfel mag bestaan oor die opregtheid van bedoeling en simpatieke gesindheid by die predikant nie, mag daar by laasgenoemde ook geen onsekerheid wees oor wat in hierdie geval gesê moet word nie. Dit is egter nie so 'n maklike saak nie, want nie alleen in die teologiese wêreld in die algemeen nie, maar ook binne ons eie kerk is daar seker nie algehele eenstemmigheid oor die beoordeling van egskeiding en oor die handeling van die kerk met sulke geskeides nie. Dit blyk al dadelik uit die houding t.o.v. die hertrou van geskeies. Die een trou elkeen wat kom. Die ander weier beslis om enige geskeie persoon te trou en albei beroep hulle op die Skrif.

\section{Aanpak van die saak}

5(i) Daar is egter enke'e sake waaroor daar geen verskil van opinie hoef te bestaan nie en wat by de pastorale bearbeiding van geskeies ter sprake behoort te kom. Sonder om in besonderhede te tree, sal die volgende in die pastorale gesprek aan die orde moet kom:

* Omdat die huwelik ' $n$ instelling van God is waartoe $\mathrm{Hy}$ een man en een vrou roep om in ' $n$ allesomvattende gemeenskap vir die volle duur van die aardse lewe getrou aan mekaar en tot lof en eer van God, saam te lewe

** dat hoewel God ons tot die huwelik roep, ons eie verantwoordelikheid by die keuse van mekaar nie uitgesluit word nie

*** dat dit God se bedoeling met die huwelik is dat hierdie verbondenheid aan mekaar onontbindbaar en onophefbaar sal wees tot dat die dood skeiding en vryheid tot ' $n$ tweede huwelik bring

**** dat die huwelik ' $n$ verbintenis tussen sondaars in ' $n$ sondige en gebroke wêreld is en dat daar om hierdie rede gewoonlik allerlei teenspoed en lyding oor die getroudes kom

***** dat ons egter ook in die huwelik uit dankbaarheid moet lewe vir die vergewing van al ons ongeregtighede en vanuit die vergewing in Christus moet leer en bereid moet wees om mekaar te vergewe en mekaar se swakhede met groot geduld moet dra, waardeur baie van die krankhede van die huwelik genees word. 
5(ii) Die doel van die pastorale gesprek met die geskeie moet wees om hom of haar tot die erkenning te bring dat elke egskeiding, om welke rede ook al - ook 'n egskeiding o.g.v. die Bybelse uitsonderingsklousule - sonde is in die oog van die Here, ' $n$ vergryp teen sy heilige wil en dat albei egliede wat by so 'n egskeiding betrokke is, skuldig staan voor God. Elkeen wat met egskeiding te doen gehad het - ek bedoel die predikant in sy pastorale sorg - weet hoe maklik die skuld altyd by die ander party gesoek word. Maar ook by die oënskynlike bona fide geval van "onskuld" sal die onskuldige sy skuld moet erken, want die egskeiding kan tot 'n mate analoog met die siekte gesien word: hoewel daar nie altyd direkte verband tussen siekte en afsonderlike sondes gelê kan word nie, moet die siekte tog teen die breër agtergrond van die sondige mensheid gesien word. So moet ook egskeiding teen die agtergrond van die algemene sondigheid van die mensheid gesien word waardeur elkeen wat daarby betrokke is skuldig staan voor God. Die pastorale handeling met die geskeie sal vrugteloos wees as dit nie tot skulderkenning en -belydenis lei nie.

5 (iii) Dit is egter nie die enigste doel van die pastorale volg. Die uiting en die bepaling van die egtheid van berou tot bevrediging van die opsighoudende liggaam in die gemeente is egter ' $n$ moeilike saak. Slegs ' $n$ woord te dien effekte is seker nie voldoende nie. By die woord sal ook die daad gevoeg moet word. 'n Berouvolle mens is iemand wat sy skuld voortdurend voor God in die gemeente bely. Dis die enigste sekere getuienis vir die kerkraad van die opregtheid van berou aan die kant van die skuldige. Hy wat so berou betoon, sal dan ook die getuienis en versekering van die evangelie verneem dat daar by God vergewing is van die sonde van egskeiding. Indien die pastorale bearbeiding nie hierdie gevolg het nie deurdat daar weerstand van die kant van die geskeie ondervind word en 'n ontwil tot skulderkenning en beroubetoning, sal die kerkraad die opsig moet verskerp in die tughandeling.

\section{Die probleem van die herirou}

6(i) Met die betoning van berou is ciie pastorale handeling met die geskeie egtcr nog nie afgehandel nie. Die probleem van die hertrou van geskeies moet nou ter sprake gebring word. As dit volgens getuienis van die Bybel tot ontug lei as 'n geskeie persoon weer sou trou met iemand anders as die vorige eggenoot, sal dit by die pastorale sorg baie pertinent aan die geskeie gestel moet word. Op hierdie punt is daar verskil van opinie. Die een standpunt - veral van Rome, maar ook van somm:ge protestante - is dat die huwelik nooit ongedaan gemaak $k a n$ word nie. Inhoudbare omstandighede kan wel daartoe lei dat man en vrou skei, dit beteken egter nie dat hulle huwelik daarmee opgehef word nie. 'n Volgende huwelik is derhalwe ook uitgesluit. Die geskeies moet óf nie weer trou nie of 
tot versoening met mekaar kom en hertrou. Ter ondersteuning van hierdie standpunt woid die voljende getuienis aangevoer:

* Die uitsonderingsklousule waardeur egskeiding veroorloof is: "behalwe omrede van hoerery", vind ons slegs in een van die vier evangelies, nl. Matt. 5:3, 19:9.

** By Markus en Lukas ontbreek hierdie uitsondering. Mark. 10:11: Elkeen wat van sy vrou skei en 'n ander een trou, pleeg egbreuk teen haar.

Luk. 16:18: Elkeen wat van sy vrou skei en 'n ander een trou, pleeg egbreuk, en elkeen wat trou met die vrou wat van haar man geskei is, pleeg egbreuk.

*** Rom. 7:3: Daarom dan, as sy 'n ander man s'n word terwyl haar man lewe, sal sy 'n egbreekster genoem word.

**** 1 Kor. 7:11: . . en as sy tog van hom skei, moet sy ongetroud bly, of haar met haar man versoen.

6(ii) Teenoor hierdie tekste wat op die oog af sterk getuienis lewer teen 'n volgende huwelik, staan die ander standpunt wat beweer dat dit vir 'n Jood, Griek en Romein so vanselfsprekend was dat ontug ' $n$ wettige grond vir egskeiding was, dat Markus, Lukas en Paulus dit nie eers nodig geag het om dit direk te meld nie. Die uitsonderingsklousule het by hulle dus swyende geldigheid. Daarby moet die aandag daarop gevestig word dat Paulus in Rom. 7 nie direk oor die huwelik handel nie, maar dit slegs as voorbeeld gebruik ter stawing van 'n ander argument, nl. dat die dood vryheid bring. Deur die dood van Christus kom daar vir ons vryheid van die wet. En wat 1 Kor. 7 betref, Paulus praat hier vanuit die veronderstelling van die spoedige wederkoms van Christus. Die eskatologiese verwagting van sommiges in Korinthe was so opgeskerp dat hulle al wou begin lewe asof die toekoms reeds aangebreek het waar nie getrou of in die huwelik uitgegee word nie. 'n Vrou wat onder sulke belewenisse van haar man skei, moet ongetroud bly, of haar met haar man versoen.

6(iii) My eie opvatting is dat egskeiding volgens O.T. getuienis baie duidelik 'n opheffing van die huwelik beteken, waarop 'n volgcnde huwelik kon plaasvind. 'n Vrou wat van haar tweede man skei, nadat s: wettig met hom getroud was, mag egter nie weer met die eerste een trou nie. Deut. 24:1. Ook wat die N.T. betref, wil ck die utisonderingsklousule handhaaf, al word hy net deur Mattheus betuig. Immers, ook die belangrike leerstuk van die maagdelike geboorte is na my wete s'egs op die Lukasgetuienis gegrond. 'n Egskeiding o.g.v. ontug kan - maar hoef nie - die beëindiging van die huweliksverbintenis beteken, waarop 'n volgende huwelik kan volg. Die vraag is of daar ook ander gronde as ontug vir 'n opheffing van die huwelik aangevoer kan word. Daar is diegene wat 
onaanpasbaarheid as grond erken wil hê. In so 'n geval sal m.i. 'n volgencle huwelik uitgesluit wees en sal onaanpasbaarheid as in blywende ongeskikthe.d vir die huwelik aanvaar moet word.

Persoonlik is ek nie ten gunste van die aanduiding van ander gronde vir egskeiding nie, hoewel ek wil toegee dat ontug in die sin van seksuele ontrou, nie die enigste rede vir egskeiding is nie. Maar allc ander gronde wat mag bestaan, wil ek beperk deur hulle in verband te bring met 'n tweede konnotasie van die uitsonderingsklousule. Daar is volgens die Bybel ook 'n geestelike ontug wat bestaan uit die vervreemding van God. Waar 'n huwelik, om welke rede ookal, so ontaard dat sy instandhouding tot gevolg het die gevaar dat die egliede fisick en geestelik verlore kan raak, het so 'n huvielik sy grense bereik. Omrede van so 'n hoerery, so 'n vervreemding van God, moet na my mening so 'n huwelik opgehef word.

6(iv) 'n Mens sou met inagneming van omstandighede 'n geskeie persoon kon adviseer, en selfs by hom aandring, om tot versoening met die vorige eggenoot te kom en weer met hom te trou. Daar kan ook omstandighede wees waar so 'n aanbeveling onverstandig kan wees. Dit lyk my ook onverstandig om aan te beveel dat so 'n persoon verder ongetroud moet bly. Die vraag is of iemand wat reeds in geslagsgemeenskap gelewe het die vleeslike versoekinge sal kan weerstaan en of so 'n maatreël nie dalk die buitehuwelikse onkuisheid sal laat toeneem nie.

\section{Samevatting}

7(i) Samevattend: Onder die opsig en tug moet met elke geval van egskeiding gehandel word. Onordelikheid en nalatigheid wat hierdie aspek van die pastorale sorg betref, kan nie deur die kerk geduld word nie. Dis seker nie nodig om die noodsaaklikheid van sinvolle en getroue pastorale sorg in die algemeen te beklemtoon nie, wat ook voorkomend kan werk t.o.v. die probleem van egskeiding. Deur die pastorale bearbeiding moet alle betrokkenes by 'n egskeiding tot die besef gebring word dat elke egskeiding, om welke rede ook al, geen geringe sonde voor God is nie en dat sulkes uit die koninkryk van God gesluit word. Daarom moet daar opgewek word tot opregte skulderkenning en hartgrondige berou. Geskied dit, moet die vergewing van hierdie sonde ook aan die skuldiges verkondig word. Geskied dit nie, moet die bearbeiding in die verdere stadiums van die tug verskerp word. Met inagneming van besondere omstandighede, kan by so 'n persoon aangedring word om tot versoening met die ander een te kom. Indien die geskeie(s) verkies om ongetroud te bly is dit goed, maar hulle sal gewaarsku moet word teen ernstige versoekings. As hulle met iemand anders sou wou trou, sou daarteen geen beswaar ingebring kon word nie. 